\title{
Article \\ Economic Analysis of a Zero-Water Solar Power Plant for Energy Security
}

\author{
Eduardo de la Rocha Camba and Fontina Petrakopoulou *
}

Citation: de la Rocha Camba, E.; Petrakopoulou, F. Economic Analysis of a Zero-Water Solar Power Plant for Energy Security. Appl. Sci. 2021, 11, 9639. https://doi.org/10.3390/ app11209639

Academic Editor: Alberto Benato

Received: 10 September 2021

Accepted: 11 October 2021

Published: 15 October 2021

Publisher's Note: MDPI stays neutral with regard to jurisdictional claims in published maps and institutional affiliations.

Copyright: (c) 2021 by the authors. Licensee MDPI, Basel, Switzerland. This article is an open access article distributed under the terms and conditions of the Creative Commons Attribution (CC BY) license (https:// creativecommons.org/licenses/by/ $4.0 /)$.
Department of Thermal and Fluid Engineering, University Carlos III of Madrid, Avenida de la Universidad 30, Leganés, 28911 Madrid, Spain; erocha@pa.uc3m.es

* Correspondence: fpetrako@ing.uc3m.es

Abstract: Water dependency of power plants undermines energy security by making power generation susceptible to water scarcity. This study evaluates the economic performance of a novel dry-cooling system for a water-independent solar power plant. The proposed cooling system is based on the concept of earth-air heat exchangers, approaching zero environmental impact. The viability of the proposed design is discussed based on both costs and benefits, and it is compared to both conventional dry- and wet-cooling systems. The installation costs of the plant are found to be EUR $13,728 / \mathrm{kW}$, resulting in the substantial levelized cost of electricity of EUR 505.97/MWh. The net present value of the studied design assuming a water-cost saving of EUR $1 / \mathrm{m}^{3}$ is found to be MEUR -139.59. Significantly higher water prices in the future might eventually make the proposed system economically attractive when compared to water-cooling systems. However, the new system would require drastic modifications to become more attractive when compared to existing dry-cooling systems. Specific possibilities to improve it for zero-water use in thermoelectric power plants are further discussed.

Keywords: water scarcity; dry cooling; solar power plants; zero-water plants; economic analysis; energy security

\section{Introduction}

Thermal power plants withdraw and consume great volumes of water [1-3]. About $40 \%$ of water withdrawals in Europe and the United States are due to power generation, specifically due to thermal plants, while this percentage reaches $84 \%$ in China and $10 \%$ globally [4-7]. This water is mainly used for cooling purposes, i.e., to condensate the steam at the outlet of the turbine in a Rankine cycle [8]. Cooling is a critical step in both fossil and renewable energy plants that must be close to a reliable water source when using wet cooling. The main two disadvantages of water use for cooling purposes are, first, the significant environment impact and, second, the vulnerability of the plant to water availability. In direct or indirect cooling, the temperature of both the water source and the ambient air, in the case of cooling towers, is increased $[9,10]$. Part of the water used is usually returned to the water source at a higher temperature and an altered chemical composition, often including pollutants [11].

Avoiding water use in thermal plants calls for urgent solutions, considering expected water stress scenarios in various regions of the world during the next decades [12]. Water scarcity, greatly influenced by climate change, will cause water competition among different sectors with social and political conflicts [8]. Potable water and water for food production, residential use, power generation and other water-requiring processes will become scarce [13-15]. This kind of effect on power generation has already been seen during the last decades, when episodes of water scarcity occurred in countries such as France, the United States of America, India, and Australia [16]. This problem can be addressed by replacing water-based cooling systems with dry cooling systems that almost completely eliminate the use of water in thermal power plants. 
Dry cooling systems, as we know them today, are more expensive and less efficient than water-cooling systems because they depend on the usually higher temperature of the air (when compared to water) [17]. The higher air temperature leads to an increase of the steam pressure at the outlet of the turbines. This reduces the expansion in the turbine, that in turn reduces the efficiency of the Rankine cycle and the power output of the plant. The lower efficiency leads to higher environmental impacts and economic expenditures: more $\mathrm{CO}_{2}$ is emitted to the atmosphere in the case of fossil-fuel plants, larger installations of heliostats are required in concentrating solar power (CSP) plants, and the local climate may be impacted by exhausted the cooling air at a higher temperature impacting.

An earth-air heat exchanger (EAHE) is a technology used to cool and heat air mainly in residential and agricultural applications. These systems cool or heat the air through pipes buried at a certain depth, taking advantage of the relatively constant temperature of the ground [18]. EAHE systems can be open- or closed-loop and horizontal or vertical. This technology is also used with water or other heat transfer fluids, generically called ground-source heat pumps (GSHP) [19]. EAHE systems use fans to move the air through the pipes that may be made of different materials, filters to clean the air, and dehumidifiers or dryers to remove the moisture. In the case of systems using a liquid fluid instead of air, fans are replaced by hydraulic pumps [20,21].

The economics of underground small-scale heat exchangers have been evaluated through methods such as the Net Present Value (NPV), the Internal Rate of Return (IRR), or the Pay-back Period (PBP). Bansal et al. (2012) studied the IRR for a 10-year period of an earth-air tunnel integrated into an evaporative system [22]. They estimated excavation costs of USD 10/h and USD 96 for a $0.15 \mathrm{~m}$ diameter and $24.4 \mathrm{~m}$ length PVC pipe. The cost of a standard blower was USD 200, while the operation and maintenance (O\&M) costs of the whole system were estimated as $2 \%$ of the initial investment. It was found that the EAHE systems were not financially viable, in spite of the energy savings when compared to conventional systems. Li et al. (2020) realized an economic analysis of an EAHE system in severely cold regions and compared it to a conventional air-handling unit [23]. They obtained a static PBP of 2.08 years for an IRR of $8 \%$, in addition to other economic and environmental benefits. Excavation work charges were USD 732.9 for one day, each pipe with a diameter of $0.25 \mathrm{~m}$ and a length of $36 \mathrm{~m}$ had an estimated cost of USD 3225, the blower had a cost of USD 109.9, the heat recovery unit cost USD 879.5, and accessories, such as vents and indoor pipes, were estimated to cost USD 703.6. Nemati et al. (2021) evaluated the combination of EAHE with indirect evaporative cooling to reduce the water consumption of evaporative cooling systems, in arid and semi-arid regions [24]. Their analysis estimated a total investment of USD 2500, achieving electricity (in summer) and natural gas (in winter) savings of USD 112 and USD 104, respectively. Additionally, a PBP between 5.5 and 6.4 years was estimated. A methodology to minimize the costs of a GCHP system was presented by Robert and Gosselin (2014) by calculating the NPV for a 20-year lifetime with an interest rate of $6 \%$ [25]. The excavation and drilling costs were CAD 42 and CAD 40 per meter, respectively, while the piping cost was CAD 42 per meter for a standard diameter used in such applications. With the objective of minimizing the costs, their optimal design showed that $62 \%$ of the total cost was related to operating costs (i.e., energy consumption for heating) and 38\% was related to the initial investment (i.e., heat pump, drilling, excavation, and pipes). Shin et al. (2020) studied the economics of a GCHP system producing air conditioning or heating together with hot water [26]. Assuming a 20-year lifetime, a discount rate of $4 \%$, and an annual performance degradation of $1.5 \%$, they found that the initial investment for a residential building was compensated by electricity savings after an operational period of three years.

Other published studies in literature focused on the cost of the pipes that seem to be the most influential parameter in the economic performance such systems. Ascione et al. (2011) analyzed the PBP of an EAHE system for the Italian climate and estimated excavation and refilling costs for different types of soil and pipe materials [27]. For a PVC pipe and unleashed soil, the excavation and refilling costs were estimated equal to EUR $2.4 / \mathrm{m}^{3}$ and 
EUR $2.0 / \mathrm{m}^{3}$, respectively. The cost of plastic pipes with diameters of $160 \mathrm{~mm}, 315 \mathrm{~mm}$, and $400 \mathrm{~mm}$ was estimated to be EUR $8.0 / \mathrm{m}$, EUR $28.0 / \mathrm{m}$ and EUR $44.0 / \mathrm{m}$, respectively. An additional $20 \%$ was assumed for the installation of the tubes, while the costs of metallic and concrete pipes were estimated to be much higher. They concluded that EAHEs are economically viable (PBP of 5-9 years) only when excavation and refilling works are easy and cheap. Mendrinos et al. (2017) listed the cost of pipes used in their simulations of shallow geothermal energy depending on dimensions and materials [28]. They considered a price of EUR 1.92/m for a PVC-U pipe with a diameter of $32 \mathrm{~mm}$ and a thickness of $2.4 \mathrm{~mm}$, and a price of EUR $4.65 / \mathrm{m}$ for a pipe with a diameter of $63 \mathrm{~mm}$ and a thickness of $4.7 \mathrm{~mm}$. Additionally, they expected an average service life of 70 years. Thomas et al. (2016) considered a PVC pipe cost of USD 61.92/ft (USD 203.15/m) for a 24 in $(0.61 \mathrm{~m}$ ) diameter together with a 50-year service life and a repair cost of USD 1000 per year and per mile [29].

This literature review is complemented with published studies on the cost of water use in power generation. In a typical coal power plant in the United States, power generation will start to be curtailed when the price of water exceeds USD $1.22 / \mathrm{m}^{3}$ and it will shut down for a price of USD $1.70 / \mathrm{m}^{3}$ [30]. According to Kablouti (2015), water acquisition costs vary from USD $0.03 / \mathrm{m}^{3}$ in India to USD $2.1 / \mathrm{m}^{3}$ in the Middle East [9]. For example, Zhai and Rubin (2010) assumed a water cost of USD $0.26 / \mathrm{m}^{3}$ to analyze the performance and costs of a coal power plant using wet and dry cooling with and without carbon capture and storage [31]. Bustamante et al. (2016) studied the potential to approximate the use of air-cooled condensers to wet cooling technologies, indicating that the cost of dry cooling systems is 3.5-5 times higher. The difference of the two technologies reduces with the increasing value and price of the water [32].

In the present paper, the idea of cooling ambient air before it is used in the condenser of a thermoelectric plant is tested. The novel concept is based on earth-cooling air tunnels (Earth-CATs), inspired by smaller-scale EAHEs. With Earth-CATs, air driven by fans is cooled down in large-scale pipes buried underground at a depth where the temperature of the soil remains relatively constant [18]. The fans are powered by electricity generated in the plant, increasing, on the other hand, its parasitic power. In addition, the system emptied the exhaust of the air into the environment at the same temperature that it was introduced into the system. This technology has, thus, zero environmental impact.

The performance of open-loop and horizontal Earth-CATs has been technically evaluated in Ref. [16] for a 20-MW solar power plant located in the Iberian Peninsula. In that study, the viability of the system was analyzed through computational fluid dynamics (CFD), and sensitivity studies of the geometric characteristics of the pipe (diameter, length, distance between pipes, thickness, and material) and the flow conditions of the air (velocity and inlet temperature) were realized. From the results, a cooling system for cooling the air from $35^{\circ} \mathrm{C}$ down to $25^{\circ} \mathrm{C}$ was proposed.

This work estimates and evaluates the economic viability of the construction and operation of the proposed Earth-CAT system for use in a 20-MW solar tower power plant. The economic analysis of the system includes the cost of the PVC pipes of the Earth-CAT system, the fans, the filters, and dryers, together with the excavation, drilling, and O\&M costs. The integration of the system in the power plant is evaluated using the total revenue requirement (TRR) method, obtaining both the total installed costs and the levelized cost of electricity (LCOE). The obtained results are compared to plants with conventional dryand wet-cooling systems. Additionally, the NPV of the Earth-CAT system is calculated accounting for the benefits of zero-water use, and the results are compared to wet-cooling systems. A sensitivity study of the parameters influencing the total costs of the novel system is also presented. Finally, the environmental and social benefits are highlighted and future research steps for the implementation of Earth-CATs are proposed. Along with the use of renewable energy sources, this novel technology aims to contribute to sustainable and reliable power generation. 


\section{Methodology}

\subsection{Design Proposal of the Earth-CAT System}

The Earth-CAT system analyzed here has been designed for a 20-MW solar power plant with thermal storage [16]. Figure 1 shows the flow conditions assumed for the cooling air $\left(\dot{m}_{\text {Air }}\right)$ and the steam entering the air condenser of the plant from the turbine $\left(\dot{m}_{\text {Steam }}\right)$ and exiting the condenser after it has been condensed $\left(\dot{m}_{\text {Water }}\right) . \dot{m}_{\text {Steam }}$ is the same mass flow rate as $\dot{m}_{\text {Water }}$. The ambient air is cooled from $35^{\circ} \mathrm{C}$ to $25^{\circ} \mathrm{C}$ in the Earth-CAT system, and it then enters the condenser. It is heated back to $35^{\circ} \mathrm{C}$ in the condenser of the plant. For the considered operational conditions, a total air mass flow of $3956 \mathrm{~kg} / \mathrm{s}$ of air is estimated. Compared to a wet-cooling system, the air mass flow required is much larger due to the higher heat capacity and density of water. This is the principal reason why water cooling is preferred in energy applications, when possible.

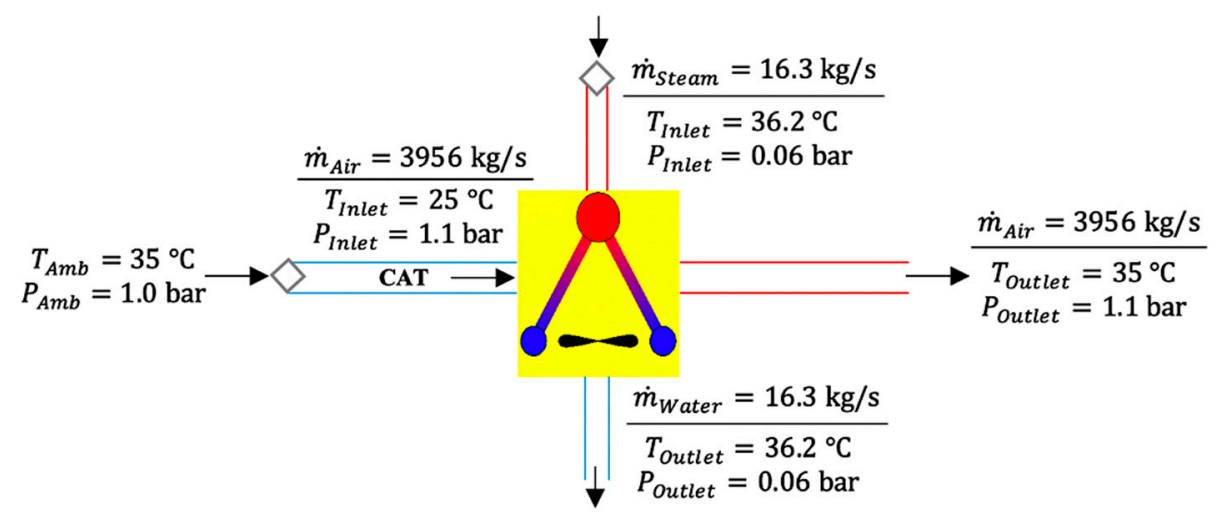

Figure 1. Simplified scheme of the air flow entering the air condenser from the Earth-CATs and the flow conditions of the steam existing the steam turbine.

Depending on the pipe geometry and the conditions of the air flow, the mass flow is divided into parallel pipes. The design that achieves the objective of cooling the air to $25^{\circ} \mathrm{C}$ involves 10,965 PVC pipes with a diameter of $0.5 \mathrm{~m}$, a length of $300 \mathrm{~m}$, a thickness of $10 \mathrm{~mm}$, and a flow velocity of $1.5 \mathrm{~m} / \mathrm{s}$ [16]. The air pressure at the inlet of the Earth-CAT system is approximately 1.1 bar to compensate for the losses in the pipes and the air condenser. This is a conservative value since the pressure losses are considered to be approximately $226 \mathrm{~Pa}$ in both the condenser and the cooling system [16].

Pipes are arranged in parallel with a distance of $1 \mathrm{~m}$ between them and are buried at a depth from $4 \mathrm{~m}$ to $10.5 \mathrm{~m}$, with five rows of pipes arranged in the vertical direction. A schematic of the design is shown in Figure 2. A total land surface of 99 hectares is required around the plant, equal to almost half of the land surface required by the 20-MW CSP plant (195 hectares) [33].

\subsection{Estimation of the Cost of the Earth-CAT System}

The costs of the project are divided into the total capital investment and the subsequent O\&M costs. The investment includes all of the material and equipment costs plus the excavation and refilling labor costs. The material costs are the piping costs, calculated from the price per length unit of a PVC pipe. A price generator for architects, engineers, and construction is used to estimate the prices of the PVC pipes [34]. The cost of a $0.5 \mathrm{~m}$ diameter PVC-U pipe depends on the nominal pressure of the design, i.e., its thickness. A pipe with a nominal pressure of $6 \mathrm{~atm}$ and a thickness of $12.3 \mathrm{~mm}$ is estimated at EUR $120.54 / \mathrm{m}$. The same kind of pipe costs EUR $185.80 / \mathrm{m}$ and EUR $277.93 / \mathrm{m}$ for nominal pressures of $10 \mathrm{~atm}$ (19.1 mm thickness) and $16 \mathrm{~atm}$ ( $29.7 \mathrm{~mm}$ thickness), respectively. For the operating pressure of 1.1 bar used in this work and applying an overpressure safety 
factor, the cost of a $0.5 \mathrm{~m}$ pipe with a nominal pressure of $1.5 \mathrm{~atm}$ is estimated with the following equation [35]:

$$
C_{P E, E a r t h-C A T}=C_{P E, R e f}\left(\frac{X_{E a r t h-C A T}}{X_{R e f}}\right)^{\alpha}
$$

where $C_{P E \text {,Earth-CAT }}$ is the purchase unit cost of Earth-CAT tubes, $C_{P E, R e f}$ is the purchase unit cost of the reference tubes, $X_{E a r t h-C A T}$ and $X_{\text {Ref }}$ are the nominal pressures of the Earth-CAT and the reference tubes, respectively, and $\alpha$ is a scaling exponent that takes into account economies of scale (here, it is assumed to be equal to 0.95 for pipes with diameters between 0.05 and $0.75 \mathrm{~m}$ ). The average unit cost estimated for the Earth-CAT system is thus calculated to be equal to EUR $30.76 / \mathrm{m}$.

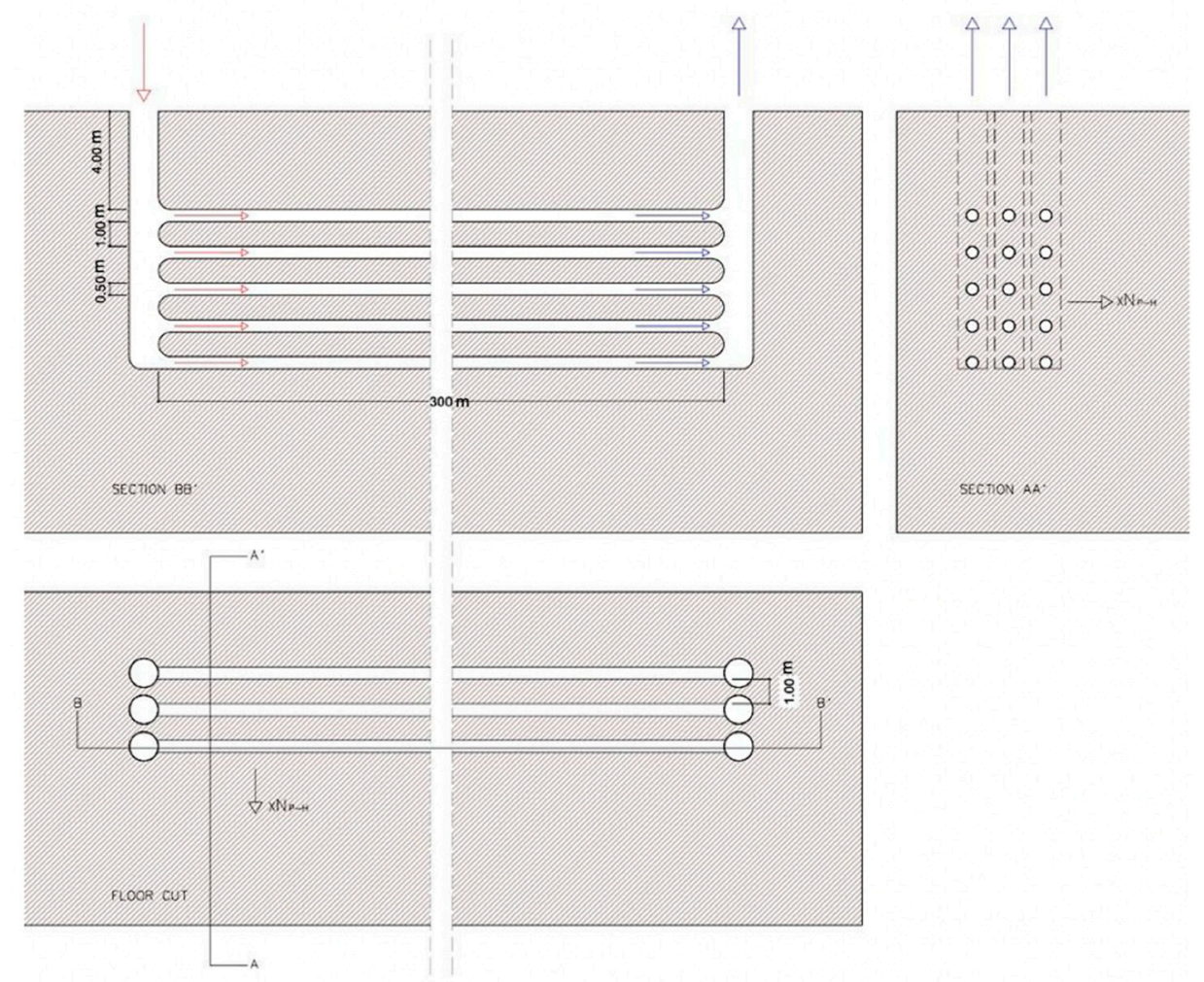

Figure 2. Sketch of the proposed design.

The power required by a fan to compensate for the pressure losses of $226 \mathrm{~Pa}$ in the pipe and the air condenser is approximately equal to $65 \mathrm{~W}$. One fan is installed for each set of 5 pipes arranged vertically, processing a flow rate of $5302.33 \mathrm{~m}^{3} / \mathrm{h}$. A standard commercial fan for a volumetric flow of $6860 \mathrm{~m}^{3} / \mathrm{h}$ (the available one found for flow rate just above $5302 \mathrm{~m}^{3} / \mathrm{h}$ ) costs EUR 319 and has a power input requirement of $760 \mathrm{~W}$ [36]. The power input is assumed to also compensate for the pressure losses within the filters and the inlet and outlet vertical pipes and is also used to drag accumulated dust by blowing the air at a higher velocity. A particle filter with a nominal volumetric flow of $3400 \mathrm{~m}^{3} / \mathrm{h}$ with a cost of EUR 100 is installed at the inlet of each 5-pipe set [37]. Thereby, a cost of EUR 156 is estimated for a nominal flow of $5302 \mathrm{~m}^{3} / \mathrm{h}$. Furthermore, dryers or dehydrator filters are also necessary, as the dew point of the water content in the air must be considered. For example, at an ambient temperature of $35^{\circ} \mathrm{C}$ and a typical relative humidity of $42 \%$ in the summer in the province of Seville, the dew point is approximately at $24{ }^{\circ} \mathrm{C}$ and condensation may occur, forming mildew inside the pipes [38]. In this work, the cost of a dehydrator filter is considered the same as that of the particle filter (EUR 156). In addition, 
the buried pipes are assumed to be slightly inclined to purge condensation [39]. Costs of electronic and electrical installations are assumed to be $10 \%$ of the equipment cost [22].

Excavation and refilling costs in unleashed soil are considered to be EUR $2.4 / \mathrm{m}^{3}$ and EUR $2.0 / \mathrm{m}^{3}$, respectively, according to the lithological map of the Iberian Peninsula [27], [40]. These costs are included in the initial investment of the project. Finally, the O\&M costs that ensure the correct operation of the system are calculated (costs of the electricity requirements, cleaning costs, repair costs, and overhauls). The electricity consumed by the fans is supplied directly by the plant itself, so a lower net power will be produced by the plant. The repair costs are estimated to be EUR 1 per meter of pipe with an increase of $2 \%$ of the total O\&M costs. The associated costs used in the model are summarized in Table 1.

Table 1. Relevant costs.

\begin{tabular}{cc}
\hline PVC Pipes (EUR/m) & 30.76 \\
Fans (EUR/unit) & 319 \\
Particle filters (EUR/unit) & 156 \\
Dehydrator filters (EUR/unit) & 156 \\
Valves, electronic, and electrical installations (\%) & $10 \%$ of equipment costs \\
Excavation (EUR $/ \mathrm{m}^{3}$ ) & 2.4 \\
Refilling (EUR $/ \mathrm{m}^{3}$ ) & 2 \\
Cleanings, overhauls and repairs of the pipes EUR $/ \mathrm{m})$ & 1 \\
Other O\&M costs $(\%)$ & 2\% of O\&M costs \\
\hline
\end{tabular}

\subsection{Economic Evaluation}

For the detailed economic analysis of the overall solar power plant, the TRR method is used [35]. Through the estimation of the initial investment of the power plant, together with the economic, financial, operating, and market parameters, the annual revenues required during the economic life of the plant are obtained. These revenues are the minimum necessary to ensure a secure and reliable operation of the plant throughout its economic life. The method results in the estimation of the LCOE, which allows us to assess the feasibility and profitability of a plant, when compared to other alternatives:

$$
L C O E=\frac{T R R-B P V}{M P Q}
$$

where $B P V$ is the revenue of the by-products (here, it is equal to zero), and $M P Q$ is the main product quantity (in this case, the electricity generated by the plant). The TRR is obtained with the sum of the escalated annual expenditures expected during the economic life of the plant:

$$
T R R=\sum_{n=0}^{N} T C R_{n}+R O I_{n}+I T X_{n}+O T X I_{n}+F C_{n}+O \& M_{n}
$$

where TCR is the total capital recovery, ROI is the minimum return on investment, ITX are the income taxes, OTXI are other taxes and insurance, and $F C$ are the fuel costs.

In this study, the proposed solar plant incorporating the Earth-CAT system is compared to a similar plant that uses first a conventional air-based cooling system and then a water-based cooling system. Table 2 summarizes the assumptions made for the detailed economic analysis [35,41]. The financing of the plant is assumed to be divided into $30 \%$ of common equity and $70 \%$ of debt, with respective required annual returns of $11 \%$ and $6.5 \%[42,43]$. The results of the economic analysis of the plant incorporating the Earth-CAT system are presented in Section 3.2, including the estimation of all the equipment costs according to the characteristics and size of the plant. 
Table 2. Assumptions of the economic analysis of the Earth-CATs and the plant.

\begin{tabular}{cc}
\hline Plant Economic Life (Years) & 25 \\
Plant life for tax purposes (years) & 20 \\
Earth-CATs economic life (years) & 25 \\
Year of beginning of design and construction period & 2022 \\
Year of beginning of commercial operation & 2024 \\
Reference year of calculations & 2021 \\
Average general inflation rate (\%) 1 & 2 \\
Average nominal escalation rate $(\%)$ & 2 \\
Average cost of money (\%) & 8 \\
\hline
\end{tabular}

${ }^{1}$ The inflation rate depends on regional characteristics and varies with time. The value here was chosen to allow the evaluation of the Earth-CAT system with conventional cooling systems under similar conditions.

The NPV and PBP are used to evaluate the viability of an investment and are used here to evaluate the zero-water operation of the Earth-CAT system, when compared to a conventional water-based cooling system. The NPV represents the present value of all the revenues and costs estimated during the economic life of a project together with the initial investment. If the NPV is positive, the investment generates profit. In order to compare the viability of the Earth-CAT system to conventional wet cooling systems, the NPV is calculated considering water-cost saving as a revenue [44]:

$$
N P V_{\text {Earth-CAT }}=-C_{0_{\text {Earth-CAT }}}+\sum_{n=0}^{N} \frac{\left(C_{W, n}-C_{O \& M, n_{\text {Earth-CAT }}}\right)}{(1+r)^{n}}
$$

where $C_{0_{\text {Earth-CAT }}}$ is the initial investment of the Earth-CAT system, $C_{W, n}$ is the water-cost saving per $\mathrm{m}^{3}, C_{O \& M, n_{E a r t h-C A T}}$ are the O\&M costs of each $n$ year during the total economic life $N$ of the Earth-CATs, and $r$ is the discount rate.

The PBP indicates the year in which the initial investment is recovered through the annual profits of the project without accounting for the value of money, and it is calculated as follows [45]:

$$
P B P_{\text {Earth-CAT }}=\frac{C_{0_{\text {Earth-CAT }}}}{\left|C_{W, n}-C_{O \& M, n_{\text {Earth-CAT }} \mid}\right|}
$$

A sensitivity analysis of parameters with a strong effect on the total costs of the EarthCAT system is presented at the end of Section 3.2. The used variables are the number of pipes, the pipe unit cost, and the gain from the avoided water. The objective is to understand how these parameters influence the viability of the system, how it can be enhanced, and propose steps for future research.

\section{Results and Discussion}

\subsection{Costs of the Earth-CAT System}

The costs of the Earth-CAT system are shown in Table 3. The chosen arrangement of the pipes requires a land surface of 99 hectares that must be excavated and refilled with labor costs of approximately MEUR 45.5. With a unit cost of EUR $30.76 / \mathrm{m}$, the total cost of the pipes is equal to MEUR 102.7, resulting in an initial investment of approximately MEUR 148.3. About $69 \%$ of the total initial investment is associated with the pipes. The pipe costs represent more than $98.5 \%$ of the material and equipment costs, while fans, filters, valves, and electronic and electrical installations have a minor influence on the investment. It is obvious that improving the economic viability of the Earth-CAT system depends on the number of pipes used and the land occupied. It is thus important to reduce the unit cost of the pipes through economies of scale.

The repair and overhaul costs are estimated considering a 25-year service life of the pipes and that, each year, $6 \mathrm{~m}$ of the total $300 \mathrm{~m}$ length of each pipe would need to be repaired. Finally, the total annual O\&M costs of EUR 67,106 represent $0.03 \%$ of the initial investment. 
Table 3. Total costs of the Earth-CAT system.

\begin{tabular}{|c|c|c|c|c|}
\hline Costs & Unit Cost & Units & $\begin{array}{l}\text { Total } \\
\text { (EUR) }\end{array}$ & $\begin{array}{l}\text { (\%) of Associated } \\
\text { Costs }\end{array}$ \\
\hline Initial investment & & & $148,285,791$ & \\
\hline Material and equipment & & & $102,707,181$ & 69.26 \\
\hline PVC pipes (material) & 30.76 EUR/m & $300 \mathrm{~m} /$ pipe $\times 10,965$ pipes & $101,185,020$ & 98.52 \\
\hline Fans & 319 EUR/unit & 2193 units & 699,567 & 0.68 \\
\hline Particle filters & $156 \mathrm{EUR} /$ unit & 2193 units & 342,108 & 0.33 \\
\hline Dehydrator filters & $156 \mathrm{EUR} /$ unit & 2193 units & 342,108 & 0.33 \\
\hline $\begin{array}{l}\text { Valves, electronic and electrical } \\
\text { installations }\end{array}$ & \multirow{2}{*}{\multicolumn{2}{|c|}{$10 \%$ extra cost of the equipment cost }} & 138,378 & 0.13 \\
\hline Labor & & & $45,578,610$ & 30.74 \\
\hline Excavation & 2.4 EUR/m $\mathrm{m}^{3}$ & $10,358,775 \mathrm{~m}^{3}$ & $24,861,060$ & 54.55 \\
\hline Refilling & $2.0 \mathrm{EUR} / \mathrm{m}^{3}$ & $10,358,775 \mathrm{~m}^{3}$ & $20,717,550$ & 45.45 \\
\hline O\&M per year & & & 67,106 & \\
\hline Cleanings, overhauls and repairs & $1 \mathrm{EUR} / \mathrm{m}$ & $6 \mathrm{~m} /$ pipe $\times 10,965$ pipes & 65,790 & 98.04 \\
\hline Others & \multicolumn{2}{|c|}{$2 \%$ extra cost of the annual O\&M cost } & 1316 & 1.96 \\
\hline
\end{tabular}

\subsection{Economic Analysis of the Overall CSP Plant}

The fixed capital investment (FCI) of the 20-MW solar power plant, with thermal storage and using the Earth-CATs, is summarized in Table 4 [41,46]. The plant is able to produce $80 \mathrm{GWh} /$ year and has a capacity factor of 55\% [33]. Direct costs include the equipment costs and consist of the solar field and the heat transfer fluid (HTF) system, the thermal storage system, the power block, and the cooling system. The solar field includes the mirrors together with the tower and the receiver. For the thermal storage, a two-tank system using molten salt that can produce $700 \mathrm{MWh}_{\text {th }}$ per day is considered, i.e., it can ensure $14 \mathrm{~h}$ of operation at maximum capacity.

The power block is a conventional steam turbine connected to the grid. Direct costs are completed with the labor costs. Costs such as the project development and management are included in the indirect costs. The total costs of the plant, including the Earth-CAT system amount to EUR 13,728/ $\mathrm{kW}$. The reported total installation costs of CSP plants with storage capacities of $8 \mathrm{~h}$ or more were in the range of EUR 3343/kW to EUR $4817 / \mathrm{kW}$ during 2018 and 2019 [47], costs significantly lower than that calculated in this study.

In addition to the FCI, the land and O\&M costs are estimated. The total surface of 195 hectares of the plant is considered to integrate the Earth-CAT system taking advantage of the buried pipes. The land cost is considered here equal to EUR $5 / \mathrm{m}^{2}$. The annual fixed O\&M costs of the plant are calculated using a specific cost of EUR $53.3 / \mathrm{kW}$, while the variable O\&M costs are estimated as $10 \%$ of the total O\&M costs. [48]. Lastly, it is assumed that 30 labor positions are required for the O\&M of the plant [35].

Based on the inputs described, and the assumptions presented in Table 2, the annual levelized TRR is estimated. The total capital investment (TCI) is obtained after adding the land costs and other outlays such as startup costs, working capital, or allowances for funds during construction. The annual capital recovery schedule is then escalated together with the rest of expenses presented in Equation (3). The overall results of the economic analysis of the plant with the Earth-CATs with a conventional air-based system and with a conventional water-based system are summarized in Table 5 . The plant with a conventional air-based system is considered to have $6.8 \%$ less annual power generation, compared to the $80 \mathrm{GWh}$ /year (i.e., $74.56 \mathrm{GWh} /$ year) [46]. For the water-based system, water costs of EUR $1 / \mathrm{m}^{3}$ are included in the annual O\&M costs [2]. The investment costs of both conventional cooling systems are considered to be part of the presented costs of the power block. During the last decade (2010-2019), the average LCOE of CSP plants decreased from EUR 283.72/MWh to EUR 149.24/MWh [49]. Specifically, for a 20-MW solar power plant using dry cooling, a TCI of MEUR 174.66 and a LCOE of EUR 138.33/MWh were obtained [46]. When wet cooling was used in the same plant, the two parameters were equal to MEUR 171.38 and EUR 126.69/MWh, respectively. 
Table 4. Fixed capital investment of the plant.

\begin{tabular}{|c|c|c|}
\hline Component & $\begin{array}{l}\text { Tota } \\
\text { (EUR) }\end{array}$ & (\%) of Investment \\
\hline \multicolumn{3}{|l|}{ Direct costs $(\mathrm{DC})$} \\
\hline Solar field and HTF system & $70,329,114$ & 25.61 \\
\hline Mirrors & $6,181,730$ & 8.79 \\
\hline Receiver & $30,000,000$ & 42.66 \\
\hline Tower & $10,000,000$ & 14.22 \\
\hline Steel construction & $10,335,080$ & 14.70 \\
\hline Pylons & $1,062,485$ & 1.51 \\
\hline Foundations & $2,028,380$ & 2.88 \\
\hline Trackers & 386,358 & 0.55 \\
\hline Swivel joints & 676,127 & 0.96 \\
\hline HTF system (piping, installations, heat exchangers, pumps) & $5,215,835$ & 7.42 \\
\hline Heat transfer fluid & $2,028,380$ & 2.88 \\
\hline Electronics, controls, electrical, and solar equipment & $2,414,738$ & 3.43 \\
\hline Thermal storage system & $15,286,964$ & 5.57 \\
\hline Salt & $7,425,097$ & 48.57 \\
\hline Storage tanks & $2,620,622$ & 17.14 \\
\hline Insulation material & 291,180 & 1.90 \\
\hline Foundations & 873,541 & 5.71 \\
\hline Heat exchangers & $2,038,262$ & 13.33 \\
\hline Pumps & 582,361 & 3.81 \\
\hline Balance of system & $1,455,901$ & 9.52 \\
\hline Conventional plant components and power system & $13,812,303$ & 5.03 \\
\hline Power block & $5,505,603$ & 39.86 \\
\hline Balance of plant & $5,505,603$ & 39.86 \\
\hline Grid connection & $2,801,096$ & 20.28 \\
\hline Cooling system & $102,707,181$ & 37.41 \\
\hline Earth-CATs dry cooling system: material and equipment & $102,707,181$ & 100 \\
\hline Labor & $62,192,010$ & 22.65 \\
\hline Solar field & $2,994,276$ & 4.81 \\
\hline Site preparation and infrastructure & $5,602,193$ & 9.01 \\
\hline Steel construction & $2,414,738$ & 3.88 \\
\hline Piping & $1,738,612$ & 2.80 \\
\hline Electric installations and others & $3,863,581$ & 6.21 \\
\hline Earth-CATs dry cooling system: labor & $45,578,610$ & 73.29 \\
\hline \multicolumn{3}{|l|}{ Indirect costs (IC) } \\
\hline Total IC & $10,238,490$ & 3.73 \\
\hline Project development & $2,801,096$ & 27.36 \\
\hline Project management & $7,437,394$ & 72.64 \\
\hline \multicolumn{3}{|l|}{ Other costs (allowances) } \\
\hline FCI & $274,566,062$ & - \\
\hline FCI without Earth-CATs & $126,280,271$ & - \\
\hline
\end{tabular}

Table 5. Results of the economic analysis of the CSP plant with Earth-CAT system with conventional air-based and water-based systems.

\begin{tabular}{cccc}
\hline & Earth-CATs & $\begin{array}{c}\text { Conventional } \\
\text { Dry-Cooling }\end{array}$ & $\begin{array}{c}\text { Conventional } \\
\text { Water-Cooling }\end{array}$ \\
\hline Total installed costs & 13,728 & 6314 & 6414 \\
(EUR/kW) & 274.57 & 126.28 & 126.28 \\
FCI (MEUR) & 9.75 & 9.75 & 9.75 \\
Land costs (MEUR) & 1.20 & 1.13 & 1.70 \\
O\&M costs (MEUR) & 321.28 & 154.17 & 154.23 \\
TCI (MEUR) & 40.48 & 20.11 & 20.83 \\
Levelized TRR (MEUR) & 505.97 & 269.71 & 260.42 \\
LCOE (EUR/MWh) & & & \\
\hline
\end{tabular}


As presented in the table above, the influence of the costs of the Earth-CATs on the total costs of the plant is significant. When compared to conventional dry-cooling systems, both the TRR and LCOE are approximately $50 \%$ higher. It is thus clear that the design proposal assumes a significant increase in the costs when compared to a plant with a conventional dry-cooling system. The cost of the Earth-CATs must reduce significantly or the additional power generation of the plant due to the higher operational efficiency must be significantly higher. For the LCOE between both dry-cooling plants to become equal, the initial investment of the Earth-CATs must decrease by almost MEUR 140 (Figure 3). The competitiveness of the technology could thus only be supported by additional benefits from a higher efficiency of the Rankine cycle.

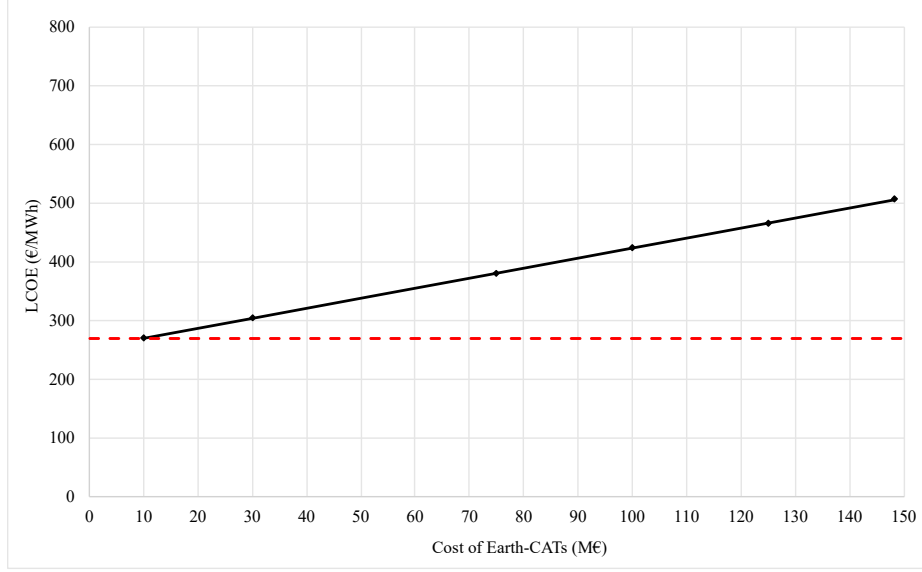

Figure 3. Effect of cost of the Earth-CATs on the LCOE of the studied plant and comparison with the plant using conventional dry-cooling (dashed line).

When compared to wet-cooling systems, the TRR and LCOE are $48.5 \%$ higher. As described in Section 2.3, the NPV and PBP are used to evaluate the costs of the Earth-CATs and compared them to water-cooling systems assuming water-cost saving as revenues. A water cost of EUR $1 / \mathrm{m}^{3}$ and annual savings due to zero-water withdrawal and consumption of $6.3 \mathrm{~m}^{3} / \mathrm{MWh}$ are considered [2]. This generates for the studied plant annual operating savings of EUR 536,000. The NPV of the Earth-CAT design with a 25-year lifetime and a discount rate of $2 \%$ is found to be MEUR -139.59 . The project is thus found to not be economically viable, since its investment is not compensated by the water-cost saving of the plant during the 25-year operation. The economic viability depends first on enhancing the technical performance of Earth-CATs to reduce the number of pipes required, while economies of scale should be applied at the same time. A higher water price will also strongly affect the results and increase the annual savings. To reveal the influence of such important parameters to the overall results and determine the values that constitute the investment profitable, sensitivity analyses are realized and presented below.

\subsubsection{Studying the Effect of the Number of Pipes}

The number of pipes required depends on their geometry and the flow conditions of the air. As observed in Ref. [16], smaller diameters, longer lengths, and lower velocities improve the performance of Earth-CATs, but a greater amount of pipes are then necessary for the total air flow required by the plant. The equilibrium between the thermal performance to cool the air down to $25^{\circ} \mathrm{C}$ and the geometry of the tubes to minimize the pipe number and thus the land required takes to the total 10,965 pipes. Nevertheless, given the economic results of this project, it is obvious that the heat transfer between the air and the soil must be improved. For example, using corrugated walls in the pipes or enhancing the conductivity of the soil by moistening it, the air velocity can be increased, and the pipe number reduced. Alternatively, the length of the pipes can be shorter, but the pressure 
losses must be known to calculate the power of the fans. The influence of the pipe length is not studied here.

The obtained results of the sensitivity analysis for the material and equipment costs, the labor costs, the O\&M costs, and the NPV are summarized in Table 6. Assuming an enhancement of the thermal performance allows for a lower number of pipes (for the assumed 25-year lifetime and the discount rate of $2 \%$ ), although the NPV notably increases as the number of pipes decrease, it remains negative. The percentage-wise reduction of the pipe number is analogous to the associated costs, due to their linear dependency. For example, the associated costs decrease by approximately $27 \%$ and $54 \%$ when the total pipe number is reduced by 2965 and 5965 pipes, respectively. This will be useful in future research because the improvement of the performance in terms of reducing the number of pipes allows us to immediately estimate the NPV and know if the project becomes economically viable relative to a water-based cooling system.

Table 6. Influence of the pipe number on the associated costs and the NPV of the project.

\begin{tabular}{ccccc}
\hline $\begin{array}{c}\text { Pipe Number } \\
(-)\end{array}$ & $\begin{array}{c}\text { Material and } \\
\text { Equipment } \\
\text { Costs } \\
\text { (MEUR) }\end{array}$ & $\begin{array}{c}\text { Labor } \\
\text { Costs } \\
\text { (MEUR) }\end{array}$ & $\begin{array}{c}\text { O\&M Costs } \\
\text { (EUR/year) }\end{array}$ & $\begin{array}{c}\text { NPV } \\
\text { (MEUR) }\end{array}$ \\
\hline 10,965 & 102.71 & 45.58 & 67,106 & -139.59 \\
8000 & 74.93 & 33.25 & 48,960 & -99.15 \\
5000 & 46.83 & 20.78 & 30,600 & -58.24 \\
3000 & 28.10 & 12.46 & 18,360 & -30.96 \\
1000 & 9.37 & 4.14 & 6120 & -3.69 \\
\hline
\end{tabular}

\subsubsection{Studying the Effect of the Pipe Unit Cost}

The reduction in the number of pipes should be combined with a lower unit cost by applying higher economies of scale due to the great number of pipes required. Table 7 shows the influence of the pipe unit cost on the initial investment and on the NPV of the project for different pipe numbers analyzed in the previous subsection. The NPV is notably increased with decreasing pipe unit cost, but it only becomes positive for a pipe number of 1000 and a pipe unit cost of EUR 15/m, which seems to be unrealistic for the set technical requirements of the studied plant.

The application of economies of scale will be a very important step to reduce the initial investment of Earth-CATs. For example, by decreasing the unit cost by approximately $35 \%$ (that is, a unit cost equal to EUR $20 / \mathrm{m}$ ), the initial investment decreases by $24 \%$ in all cases. However, the application of economies of scale, together with the reduction of the pipe number, are not enough to constitute the project profitable. For the Earth-CAT system to become economically viable relative to a water-based cooling system, the annual savings for zero-water use must be higher. The cost of water use is analyzed in the following subsection.

\subsubsection{Studying the Effect of the Cost of Water}

Future water scarcity, predicted for large regions of the planet, will cause an increase in the cost of water that will be proportional to the magnitude of the conflicts that arise. Specifically in power generation, the price of water could reach values of up to EUR $50 / \mathrm{m}^{3}$, while the possibility of water trading between different sectors has been recently confirmed with the entrance of water in the Wall Street markets [50,51]. A water cost of EUR 50/ $\mathrm{m}^{3}$ is much higher than current water costs for water-cooling systems and water generation technologies [9]. Nevertheless, in a comparative analysis, this price should include other associated costs on top of the base price of water used. For example, it should account for water generation and treatment, transport, power penalties related to water shortages, lower power output due to the deterioration of physical characteristics of the water, and economic or environmental impacts to the local climate and population [52]. Such external- 
ities are usually currently neglected in economic analyses found in the literature but could help to better evaluate the cost of water and establish a fairer basis for the comparison of different cooling technologies.

Table 7. Influence of the pipe cost on the initial investment and the NPV of the Earth-CAT system.

\begin{tabular}{ccccc}
\hline $\begin{array}{c}\text { Pipe Number } \\
(-)\end{array}$ & $\begin{array}{c}\text { Pipe Unit Cost } \\
\text { (EUR/m) }\end{array}$ & $\begin{array}{c}\text { Total Pipe Costs } \\
\text { (MEUR) }\end{array}$ & $\begin{array}{c}\text { Initial } \\
\text { Investment } \\
\text { (MEUR) }\end{array}$ & $\begin{array}{c}\text { NPV } \\
\text { (MEUR) }\end{array}$ \\
\hline \multirow{3}{*}{10,965} & 30.76 & 102.71 & 148.29 & -139.59 \\
& 25.00 & 83.76 & 129.34 & -120.64 \\
& 20.00 & 67.31 & 112.89 & -104.20 \\
& 15.00 & 50.86 & 96.44 & -87.75 \\
8000 & 10.00 & 34.42 & 80.00 & -71.30 \\
& 30.76 & 74.93 & 108.18 & -99.15 \\
& 25.00 & 61.11 & 94.36 & -85.33 \\
& 20.00 & 49.11 & 82.36 & -73.33 \\
& 15.00 & 37.11 & 70.36 & -61.33 \\
5000 & 10.00 & 25.11 & 58.36 & -49.33 \\
& 30.76 & 46.83 & 67.61 & -58.24 \\
& 25.00 & 38.19 & 58.97 & -49.60 \\
& 20.00 & 30.69 & 51.47 & -42.10 \\
& 15.00 & 23.19 & 43.97 & -34.60 \\
& 10.00 & 15.69 & 36.47 & -27.10 \\
& 30.76 & 28.10 & 40.56 & -30.96 \\
& 25.00 & 22.92 & 35.38 & -25.78 \\
& 20.00 & 18.42 & 30.88 & -21.28 \\
& 15.00 & 13.92 & 26.38 & -16.78 \\
& 10.00 & 9.42 & 21.88 & -12.28 \\
& 30.76 & 9.37 & 13.51 & -3.69 \\
& 25.00 & 7.64 & 11.78 & -1.96 \\
& 20.00 & 6.14 & 10.28 & -0.46 \\
& 15.00 & 4.64 & 8.78 & 1.04 \\
& 10.00 & 3.14 & 7.28 & 2.54 \\
\hline
\end{tabular}

The cost of water in the power generation sector will play a decisive role in the implementation of the Earth-CATs as an alternative cooling system. The variation of the water cost on the NPV is presented in Table 8 (again, for a 25-year lifetime and a discount rate of $2 \%$ ). The design starts being economically viable for a water cost higher than EUR $15 / \mathrm{m}^{3}$. For a water cost of EUR $16 / \mathrm{m}^{3}$, the NPV value is equal to MEUR 9.51 and the PBP is equal to 17.4 years. Furthermore, if future research improves the thermal performance of Earth-CATs and reduces the number of pipes required to 8000 while having a pipe unit cost of EUR $25 / \mathrm{m}$, the project will be viable for a water cost of EUR $10 / \mathrm{m}^{3}$ with a NPV of MEUR 4.12 and an investment recovery after 17.8 years. These hypothetical cases allow us to understand how competitive an Earth-CAT system is relative to a conventional water-cooled system as a zero-water cooling alternative, and they set important references for future research.

In the case of plants using wet cooling, the LCOE is expected to increase with the water cost. Figure 4 shows the effect of water cost on the LCOE of the studied CSP plant if wet cooling is used. It is for a water cost of approximately EUR $28 / \mathrm{m}^{3}$ that the obtained LCOE meets that of the plant using Earth-CATs (EUR 505.97/MWh). Although this water cost would include the externalities associated to its use and may be a potential future, there is a need to reduce the large initial investment of the project, involving the improvement of the heat transfer between the Earth-CAT and the soil, applying economies of scale on the unit price of the pipes, and accounting for the cost of water. In addition, policies supporting sustainable energy reforms could favor the economic viability of the system, reducing the investment costs and promoting the use of Earth-CAT systems over conventional cooling systems. 
Table 8. Influence of the water cost on the NPV of the Earth-CAT system.

\begin{tabular}{|c|c|c|c|c|}
\hline $\begin{array}{c}\text { Pipe Number } \\
(-)\end{array}$ & $\begin{array}{l}\text { Pipe Unit Cost } \\
\text { (EUR/m) }\end{array}$ & $\begin{array}{l}\text { Water Cost } \\
\left(E U R / m^{3}\right)\end{array}$ & $\begin{array}{c}\text { NPV } \\
\text { (MEUR) }\end{array}$ & $\begin{array}{c}\text { PBP } \\
\text { (Years) }\end{array}$ \\
\hline \multirow{5}{*}{10,965} & \multirow{5}{*}{30.76} & 1 & -139.59 & - \\
\hline & & 5 & -99.83 & - \\
\hline & & 10 & -50.14 & - \\
\hline & & 15 & -0.44 & - \\
\hline & & 20 & 49.25 & 13.9 \\
\hline \multirow{5}{*}{10,965} & \multirow{5}{*}{25.00} & 1 & -120.64 & - \\
\hline & & 5 & -80.89 & - \\
\hline & & 10 & -31.19 & - \\
\hline & & 15 & 18.50 & 16.2 \\
\hline & & 20 & 68.20 & 12.1 \\
\hline \multirow{5}{*}{8000} & \multirow{5}{*}{30.76} & 1 & -99.15 & - \\
\hline & & 5 & -59.40 & - \\
\hline & & 10 & -9.70 & - \\
\hline & & 15 & 39.99 & 13.5 \\
\hline & & 20 & 89.69 & 10.1 \\
\hline \multirow{5}{*}{8000} & \multirow{5}{*}{25.00} & 1 & -85.33 & - \\
\hline & & 5 & -45.57 & - \\
\hline & & 10 & 4.12 & 17.8 \\
\hline & & 15 & 53.82 & 11.8 \\
\hline & & 20 & 65.82 & 10.3 \\
\hline
\end{tabular}

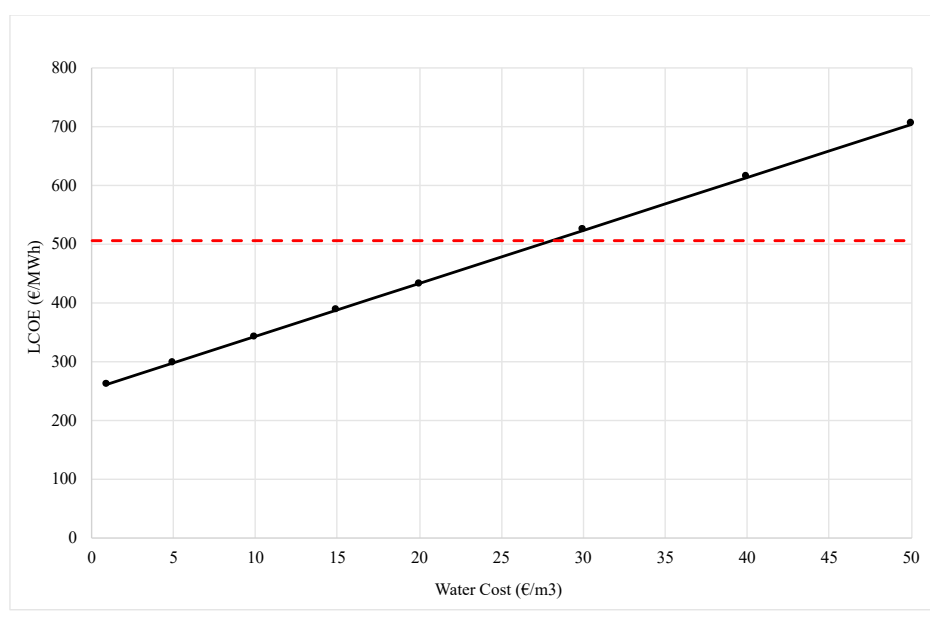

Figure 4. Effect of the water cost on the LCOE of the studied plant using wet cooling and comparison with the plant using Earth-CATs (dashed line).

\subsection{Environmental and Social Considerations}

The environmental and social benefits of the Earth-CATs are not economically evaluated here, but a model to quantify them, in terms of revenues or funding by governments or other public administrations, would allow for a more thorough economic analysis. The social and environmental benefits of avoided water are significant not only in CSP plants but also in all thermoelectric plants, even more so if the efficiency of the power plant remains constant for zero-water operation, that is the case with Earth-CATs.

Earth-CATs enjoy all the benefits of dry-cooling systems and more. The water saved would be available for other sectors, such as residential use or irrigation. The cooling system eliminates thermal and chemical environmental impacts of water-cooled power plants. Moreover, it allows for a reliable power generation by making the plant not vulnerable to water shortages and reducing the dry-cooling plant's dependency on the 
ambient temperature. These benefits would lead to sustainable plants with close to zero environmental implications.

Therefore, the benefits of avoiding water use for cooling purposes must be analyzed with a life cycle assessment (LCA) throughout the whole life cycle of the plant. As mentioned, the cost of water should account for all relevant externalities: all of the required steps to make cooling water available to the arid region of the power plant (e.g., piping, desalination, transport supported by fossil or alternative fuels), the environmental impact on the qualitative and quantitative characteristics of the water/air used (the air used in air-cooling systems is returned to the environment at a higher temperature), as well as to account for the power reduction related to the use of high-temperature ambient air or cooling water availability shortages over the annual operation of the plant. A detailed LCA could lead to a more accurate estimation of annual savings due to the water avoided. Together with the potential governmental or other public administration support for sustainable operation, Earth-CATs could become more favorable economically.

An important environmental concern of the Earth-CAT system that must be mentioned is the great volume of PVC material that would be required for the production of the pipes. Comparing different materials, not only based on their heat transfer properties and costs but also based on their environmental impact, would contribute to the optimization of the system. For example, compared to metal materials such as stainless steel, PVC has a higher impact because it takes a much longer time to degrade, it has a lower recycling rate, and may have a lower service life. On the other hand, it may consume less energy during its production and transportation [53]. A potential solution to reduce the impact of PVC pipes is to use recycled PVC, which contributes to remarkable savings of energy and emissions without diminishing other properties [54].

\section{Conclusions}

This work presented the economic evaluation of a novel dry-cooling system based on earth-air heat exchangers (Earth-CAT system). The aim of the system is to eliminate the use of water for cooling purposes and support water-independent power systems that can operate securely under challenging future water-scarcity conditions. The proposed system was analyzed as part of a 20-MW solar power plant, and it was compared to both conventional air-based (dry) and water-based cooling systems.

To analyze the economic performance of the plant, the TRR method was used. The levelized TRR and LCOE for an economic life of 25 years was found to be MEUR 40.48 and EUR 505.97/MWh, respectively. The total installed costs of the plant were EUR 13,728/kW. The use of Earth-CATs resulted in much higher levelized TRR and LCOE when compared to a plant using a conventional water-cooling system and approximately double the costs when compared to a plant using a conventional dry-cooling system. The proposed system is thus not currently competitive with conventional cooling systems.

Earth-CATs could become competitive relative to a water cooling for a water cost higher than EUR $28 / \mathrm{m}^{3}$. In addition, a water cost of EUR $16 / \mathrm{m}^{3}$, result in a NPV and PBP of MEUR 9.51 and 17.4 years, respectively. Although this water cost seems high, when compared to current costs, forecasts of future costs in the power generation sector foresee even higher values. Nevertheless, for the system to become competitive with dry-cooling systems, further significant improvement should take place. From a technical point of view, improvements could include a closed-loop system to eliminate the dependency of the system on the ambient temperature. The number of pipes could be reduced though thermal performance improvement. An increase in the contact surface between the air and the PVC pipes or the study of the thermal response of the soil could a reduction in the number of pipes and land surface required. Such an optimized design could reduce the associated costs and make the system more competitive with existing cooling systems. Applying higher economies of scale would also play an important role in reducing the unit cost of the pipes. In addition, using more sophisticated economic methodologies such as using the Real Options Approach could enhance the accuracy of the analysis. Further 
research should include additional consideration of social and environmental benefits in terms of economic revenues, the implementation of energy policies, and a life cycle analysis of the overall plant.

Author Contributions: Conceptualization, F.P.; methodology, E.d.1.R.C., F.P.; validation, E.d.1.R.C.; writing-original draft preparation, E.d.1.R.C., F.P.; writing-review and editing E.d.1.R.C., F.P.; supervision, F.P. All authors have read and agreed to the published version of the manuscript.

Funding: Fontina Petrakopoulou received funding from the Spanish Ministry of Science, Innovation and Universities and the Universidad Carlos III de Madrid (Ramón y Cajal Programme, RYC-2016-20971).

Data Availability Statement: All data are available upon request.

Conflicts of Interest: The authors declare no conflict of interest.

\section{References}

1. Larsen, M.A.D.; Drews, M. Water Use in Electricity Generation for Water-Energy Nexus Analyses: The European Case. Sci. Total. Environ. 2019, 651, 2044-2058. [CrossRef] [PubMed]

2. Dooley, J.J.; Kyle, P.; Davies, E.G. Climate Mitigation's Impact on Global and Regional Electric Power Sector Water Use in the 21st Century. Energy Procedia 2013, 37, 2470-2478. [CrossRef]

3. Huang, W.; Ma, D.; Chen, W. Connecting Water and Energy: Assessing the Impacts of Carbon and Water Constraints on China's Power Sector. Appl. Energy 2017, 185, 1497-1505. [CrossRef]

4. Pan, S.-Y.; Snyder, S.W.; Packman, A.I.; Lin, Y.J.; Chiang, P.-C. Cooling Water Use in Thermoelectric Power Generation and its Associated Challenges for Addressing Water-Energy Nexus. Water-Energy Nexus 2018, 1, 26-41. [CrossRef]

5. van Vliet, M.T.; Yearsley, J.R.; Ludwig, F.; Vögele, S.; Lettenmaier, D.P.; Kabat, P. Vulnerability of US and European Electricity Supply to Climate Change. Nat. Clim. Chang. 2012, 2, 676-681. [CrossRef]

6. Rodriguez, D.J.; Delgado, A.; DeLaquil, P.; Sohns, A. Thirsty Energy; World Bank: Washington, DC, USA, 2013.

7. Rübbelke, D.; Vögele, S. Impacts of Climate Change on European Critical Infrastructures: The Case of the Power Sector. Environ. Sci. Policy 2011, 14, 53-63. [CrossRef]

8. Zhou, Q.; Hanasaki, N.; Fujimori, S. Economic Consequences of Cooling Water Insufficiency in the Thermal Power Sector under Climate Change Scenarios. Energies 2018, 11, 2686. [CrossRef]

9. Kablouti, G. Cost of Water Use: A Driver of Future Investments into Water-efficient Thermal Power Plants? Aquat. Procedia 2015, 5, 31-43. [CrossRef]

10. Kohli, A.; Frenken, K. Cooling Water for Energy Generation and Its Impact on National-Level Water Statistics; Food and Agriculture Organization: Rome, Italy, 2011.

11. Delgado, A. Water for Thermal Power Plants: Understanding a Piece of the Water Energy Nexus. Glob. Water Forum 2015, 3-8, 441.

12. UNESCO. United Nations World Water Development Report 2020; UN-Water: Paris, France, 2020.

13. Gosling, S.N.; Arnell, N.W. A Global Assessment of the Impact of Climate Change on Water Scarcity. Clim. Chang. 2016, 134, 371-385. [CrossRef]

14. WWAP (UNESCO World Water Assessment Programme). The United Nations World Water Development Report 2019: Leaving No One Behind; UN-Water: Paris, France, 2019.

15. Maddocks, A.; Young, R.S.; Reig, P. Ranking the World's Most Water-Stressed Countries in $2040 . \quad$ Available online: file:/ / /Users/eduardo/Library / Application\%20Support/Mendeley\%20Desktop/Downloaded/5ed9de59f7c71800dbe3 1db1508d085c179419b0.html (accessed on 2 April 2020).

16. de la Rocha Camba, E.; Petrakopoulou, F. Earth-Cooling Air Tunnels for Thermal Power Plants: Initial Design by CFD Modelling. Energies 2020, 13, 797. [CrossRef]

17. Hooman, K.; Guan, Z.; Gurgenci, H. Advances in Dry Cooling for Concentrating Solar Thermal (CST) Power Plants; Woodhead Publishing: Duxford, UK; Elsevier Ltd: Amsterdam, The Netherlands, 2017; pp. 179-212.

18. Bisoniya, T.S.; Kumar, A.; Baredar, P. Study on Calculation Models of Earth-Air Heat Exchanger Systems. J. Energy 2014, 2014, 859286. [CrossRef]

19. Soni, S.K.; Pandey, M.; Bartaria, V.N. Ground Coupled Heat Exchangers: A Review and Applications. Renew. Sustain. Energy Rev. 2015, 47, 83-92. [CrossRef]

20. Florides, G.; Kalogirou, S. Ground Heat Exchangers-A Review of Systems, Models and Applications. Renew. Energy 2007, 32, 2461-2478. [CrossRef]

21. Aresti, L.; Christodoulides, P.; Florides, G. A Review of the Design Aspects of Ground Heat Exchangers. Renew. Sustain. Energy Rev. 2018, 92, 757-773. [CrossRef]

22. Bansal, V.; Misra, R.; Das Agrawal, G.; Mathur, J. Performance Evaluation and Economic Analysis of Integrated Earth-Air-Tunnel Heat Exchanger-Evaporative Cooling System. Energy Build. 2012, 55, 102-108. [CrossRef]

23. Li, H.; Ni, L.; Yao, Y.; Sun, C. Annual Performance Experiments of an Earth-Air Heat Exchanger Fresh Air-Handling Unit in Severe Cold Regions: Operation, Economic and Greenhouse Gas Emission Analyses. Renew. Energy 2020, 146, 25-37. [CrossRef] 
24. Nemati, N.; Omidvar, A.; Rosti, B. Performance Evaluation of a Novel Hybrid Cooling System Combining Indirect Evaporative Cooler and Earth-Air Heat Exchanger. Energy 2021, 215, 119216. [CrossRef]

25. Robert, F.; Gosselin, L. New Methodology to Design Ground Coupled Heat Pump Systems Based on Total Cost Minimization. Appl. Therm. Eng. 2014, 62, 481-491. [CrossRef]

26. Shin, J.S.; Kim, S.H.; Park, J.W. Economic Analysis of Integrated Ground Source Heat Pumps on a Shared Ground Loop. Energies 2020, 13, 2928. [CrossRef]

27. Ascione, F.; Bellia, L.; Minichiello, F. Earth-to-Air Heat Exchangers for Italian Climates. Renew. Energy 2011, 36, 2177-2188. [CrossRef]

28. Mendrinos, D.; Katsantonis, S.; Karytsas, C. Review of Alternative Pipe Materials for Exploiting Shallow Geothermal Energy. Corros. Mater. 2017, 7, 13-29. [CrossRef]

29. Thomas, A.; Mantha, B.R.K.; Menassa, C.C.; Livingston, B.L.; Cate, C.; Pridmore, A.; Heidrick, J.W.; Geisbush, J. A Framework to Evaluate the Life Cycle Costs and Environmental Impacts of Water Pipelines. Pipelines 2016 2016, 1152-1163. [CrossRef]

30. Stillwell, A.S. Is Water Price an Effective Means to Reduce Cooling Water Consumption at Thermal Power Plants? Glob. Water Forum-Econ.-Water Secur. 2019. Available online: https://globalwaterforum.org/2019/07/15/is-water-price-an-effective-meansto-reduce-cooling-water-consumption-at-thermal-power-plants / (accessed on 28 March 2020).

31. Zhai, H.; Rubin, E.S. Performance and Cost of Wet and Dry Cooling Systems for Pulverized Coal Power Plants with and Without Carbon Capture and Storage. Energy Policy 2010, 38, 5653-5660. [CrossRef]

32. Bustamante, J.G.; Rattner, A.; Garimella, S. Achieving Near-Water-Cooled Power Plant Performance with Air-Cooled Condensers. Appl. Therm. Eng. 2016, 105, 362-371. [CrossRef]

33. Gemasolar Solar Thermal Power Plant. Available online: https://www.energy.sener/projects/gemasolar\#: \{\}:text=Gemasolar\% 20is $\% 20$ able $\% 20$ to $\% 20$ produce $\% 2080 \% 20$ GWh $\% 20$ per $\% 20$ year $\% 2$ C $\% 20$ generate, year $\% 20$ the $\% 20$ CO2\%20missions (accessed on 23 May 2021).

34. Generador de Precios. España. CYPE Ingenieros, S.A. Available online: http://www.generadordeprecios.info/espacios_urbanos/ Instalaciones/Urbanas/Redes_de_agua_potable/Tubo_de_PVC_1_0_0_0_0_0_0_0_0_0_6.html (accessed on 7 April 2020).

35. Bejan, A.; Tsatsaronis, G.; Moran, M.J. Thermal Design and Optimization; Wiley-Interscience: Hoboken, NJ, USA, 1995.

36. Salvador Escoda, S.A. Tarifa de Precios Ventilación Industrial. Available online: https://www.salvadorescoda.com/tarifas/ Ventilacion_Industrial_Tarifa_PVP_SalvadorEscoda.pdf (accessed on 7 April 2020).

37. Salvador Escoda, S.A.; Filtración, I.S.O. Tarifa de Precios Filtros. Available online: https://www.salvadorescoda.com/tarifas/ Campanas_Filtros_Tarifa_PVP_SalvadorEscoda.pdf (accessed on 8 April 2020).

38. AEMET. Estadística de las Variables Meteorofenológicas. Available online: http://www.aemet.es/es/datos_abiertos/estadisticas / estadistica_meteorofenologicas (accessed on 8 April 2020).

39. Singh, R.; Sawhney, R.; Lazarus, I.; Kishore, V. Recent Advancements in Earth Air Tunnel Heat Exchanger (EATHE) System for Indoor Thermal Comfort Application: A Review. Renew. Sustain. Energy Rev. 2018, 82, 2162-2185. [CrossRef]

40. Tejero de la Cuesta, J.M. Litología de España-Maplanos. Available online: https:/ / maplanos.com/litologia/ (accessed on 8 April 2020).

41. Petrakopoulou, F. Scenarios for the Sustainable Development of Energy Autonomy of Skyros—GENERGIS (Green Energy for Islands); National Technical University of Athens: Athens, Greece, 2015.

42. Kost, C.; Schlegl, T.; Thomsen, J.; Nold, S.; Mayer, J.; Hartmann, N.; Senkpiel, C.; Philipps, S.; Lude, S.; Saad, N. Fraunhofer ISE: Levelized Cost of Electricity-Renewable Energy Technologies, March 2018. Available online: https://www.ise.fraunhofer.de/ en/publications/studies / cost-of-electricity.html (accessed on 1 September 2021).

43. Miguel, G.S.; Corona, B. Economic Viability of Concentrated Solar Power under Different Regulatory Frameworks in Spain. Renew. Sustain. Energy Rev. 2018, 91, 205-218. [CrossRef]

44. Go, G.-H.; Lee, S.-R.; Yoon, S.; Kim, M.-J. Optimum Design of Horizontal Ground-Coupled Heat Pump Systems Using SpiralCoil-Loop Heat Exchangers. Appl. Energy 2016, 162, 330-345. [CrossRef]

45. Chel, A.; Tiwari, G.N. Performance Evaluation and Life Cycle Cost Analysis of Earth to Air Heat Exchanger Integrated with Adobe Building for New Delhi Composite Climate. Energy Build. 2009, 41, 56-66. [CrossRef]

46. Boukelia, T.; Bouraoui, A.; Laouafi, A.; Djimli, S.; Kabar, Y. 3E (Energy-Exergy-Economic) Comparative Study of Integrating Wet and Dry Cooling Systems in Solar Tower Power Plants. Energy 2020, 200, 117567. [CrossRef]

47. The Cost of Concentrated Solar Power Fell by 47\% between 2010 and 2019. Available online: https://www.evwind.es/2020/07/ 29/the-cost-of-concentrated-solar-power-fell-by-47-between-2010-and-2019/76120 (accessed on 22 May 2021).

48. IRENA - International Renewable Energy Agency. Concentrating Solar Power-Renewable Energy Technologies: Cost Analysis Series. Available online: https://www.irena.org/-/media/Files/IRENA/Agency/Publication/2012/RE_Technologies_Cost_ Analysis-CSP.pdf (accessed on 23 May 2021).

49. International Renewable Energy Agency (IRENA). Renewable Power Generation Costs in 2018. 2019. Available online: https: //www.irena.org/-/media/Files/IRENA/Agency/Publication/2018/Jan/IRENA_2017_Power_Costs_2018.pdf (accessed on 23 May 2021).

50. Khan, Z.; Linares, P.; García-González, J. Adaptation to Climate-Induced Regional Water Constraints in the Spanish Energy Sector: An Integrated Assessment. Energy Policy 2016, 97, 123-135. [CrossRef]

51. Hiltzik, M. Column: Wall Street Can Now Bet on the Price of California Water. Watch Out. Los Angeles Times, 3 January 2021. 
52. Petrakopoulou, F.; Robinson, A.; Olmeda-Delgado, M. Impact of Climate Change on Fossil Fuel Power-Plant Efficiency and Water Use. J. Clean. Prod. 2020, 273, 122816. [CrossRef]

53. Is Metal More Sustainable than Plastic? (Metal vs Plastic Comparison). Better Meets Real. 2020. Available online: https: / / bettermeetsreality.com/is-metal-more-sustainable-than-plastic-metal-vs-plastic-comparison/\#:\%7B \{\}\%7D:text=Pollution (accessed on 4 June 2020).

54. Vinyl Plus Company. PVC Recycling Technologies; Vinyl Plus: Brussels, Belgium, 2017. 